\title{
Ung kvinne med hjertestans
}

\author{
Akutt sirkulasjonsstans er utfordrende både diagnostisk og terapeutisk. \\ Vi presenterer her en kasuistikk som omhandler en ung dyspneisk \\ pasient som utviklet sirkulasjonsstans, med behov for langvarig resus- \\ citering og med liten nytte av medikamentell behandling. I forløpet ble \\ det utført både akutt kirurgi og terapeutisk hypotermi.
}

Se kommentar side 50 og kunnskapsprøve på www.tidsskriftet.no/quiz

\section{Petter Vanke \\ petter.vanke@gmail.com \\ Klinikk for hjertemedisin \\ Trond Nordseth \\ Klinikk for anestesi og akuttmedisin}

\section{Jan P. Loennechen}

Klinikk for hjertemedisin og Institutt

for sirkulasjon og bildediagnostikk, NTNU

\section{Dagmar Heinke Mostad}

Klinikk for anestesi og akuttmedisin

Terje Skjærpe

Klinikk for hjertemedisin

\section{Olav F.M. Sellevold}

og intensivmedisin

og

Norges teknisk naturvitenskapelige universitet

St. Olavs hospital

Universitetssykehuset i Trondheim

7030 Trondheim

En 20 år gammel kvinne besvimte på stasjonen etter en cirka to timers togreise. I akuttmottaket var hun blek, satt høyt på båren, var uttalt motorisk urolig, dyspneisk og klaget over brystsmerter. Systolisk blodtrykk var $140 \mathrm{~mm} \mathrm{Hg}$, puls regelmessig ca. 80 slag/min og pulsoksimetri viste verdier $<85 \%\left(\mathrm{~S}_{p} \mathrm{O}_{2}\right)$. Etter kort tid inntraff det sirkulasjonskollaps med pulsløs elektrisk aktivitet. Det ble startet basal hjerte-lunge-redning og etter 3-4 minutter var det følbar egenpuls $i$ a. carotis, men ikke $i$ a. radialis. Hun våknet til og var svært urolig, men kunne svare bekreftende på p-pillebruk. Pasienten pustet spontant, men ble støttet med $100 \%$ oksygen på maske. $\mathrm{S}_{p} \mathrm{O}_{2}$ var $<85 \%$, men det var usikker måling pga. dårlig perifer pulsasjon. Ekkokardiografisk undersøkelse ca. ti minutter etter innkomst viste en hyperkinetisk venstre ventrikkel med svært redusert fylling. Høyre ventrikkel var betydelig dilatert og hypokinetisk. Ventrikkelseptum bukte inn i venstre ventrikkel. Det var ingen tegn til perikardvæske eller hjertetampo-
Avdeling for hjerte-lunge anestesi nade (fig 1). EKG viste sinustakykardi med frekvens $140 \mathrm{slag} / \mathrm{min}, \mathrm{QRS}$-bredde $0,12 \mathrm{~mm}$, høyre grenblokk-morfologi med akse $+90^{\circ}$, ST-elevasjon 3 til ca. $10 \mathrm{~mm}$ i standardavledninger II, III, aVF samt V2-V4 og STdepresjon $2 \mathrm{~mm}$ i standardavledninger $/$ og aVL (fig 2). Ny sirkulasjonsstans inntraff ca. 15 minutter etter innkomst, og hun ble intubert og hjerte-lunge-redning kontinuert.

Hos vår pasient kunne EKG-funn og klinisk bilde være forenlig med et akutt hjerteinfarkt komplisert med ruptur av ventrikkelseptum eller papillemuskel. Pasientens alder gjorde et infarkt mindre sannsynlig og komplikasjoner ble utelukket ekkokardiografisk. Et isolert høyresidig hjerteinfarkt kunne imidlertid ikke utelukkes, men ble vurdert som mindre sannsynlig. Alvorlig myokarditt innbefatter sjelden bare høyre ventrikkel. Intoksikasjon ble initialt vurdert som en mulighet, men ble oppfattet å være mindre aktuelt da det verken ble observert funn etter venøse innstikk eller registrert alkoholisk føtor. Blodgassanalyse med utvidet svar utelukket alvorlig natriumeller kaliumforstyrrelse. Hemoglobinverdien var normal, men dette utelukket ikke en blødning i tidlig stadium. Det ble ikke funnet ek- kokardiografiske tegn til aortadisseksjon med eventuell perikardtamponade (Marfans eller Turners syndrom). Pasientens utseende var ikke syndromspreget. Cerebral katastrofe ble vurdert som mindre sannsynlig da hun initialt var cerebralt adekvat. Primær ventrikulær takyarytmi ble utelukket da pasienten var EKG-overvåket. Trykk-pneumothorax kan forekomme både spontant og etter traume, men det var ingen tegn til ytre skader og respirasjonslydene var sidelike. Dekompensert kronisk cor pulmonale kunne ikke utelukkes ekkokardiografisk, men var mindre aktuelt da denne tilstanden helst ses hos eldre pasienter med alvorlig lungesykdom.

Den første arterielle blodgassanalysen viste en kombinert metabolsk og respiratorisk acidose (blodgass 2, tab 1). Overtrykksventilasjon med $100 \%$ oksygen, brystkompresjoner og væskebehandling ble kontinuert. EKG- overvåking viste hele tiden komplekser, og tidvis hadde hun egensirkulasjon med systolisk blodtrykk 40-80 mm Hg målt $i$ a. radialis. For å opprettholde perfusjonstrykk ble det gitt fenylefrin $(0,2 \mathrm{mg} \times 5)$, adrenalin $(1 \mathrm{mg} \times 3)$ og noradrenalin infusjon $(0,5 \mu \mathrm{g} / \mathrm{kg} / \mathrm{min})$. Det ble etter hvert observert lysstive dilaterte pupiller.

Ved kardiogent sjokk og/eller hypotensjon som ikke svarer på adekvat væskebehandling, er det indisert med vasoaktive medikamenter for å opprettholde perfusjonstrykket.

Ut fra alder, p-pillebruk, betydelig hypoksi og ekkokardiografiske funn vurderte vi lungeemboli som den mest sannsynlige diagnosen. Lungeemboli gir varierende grad

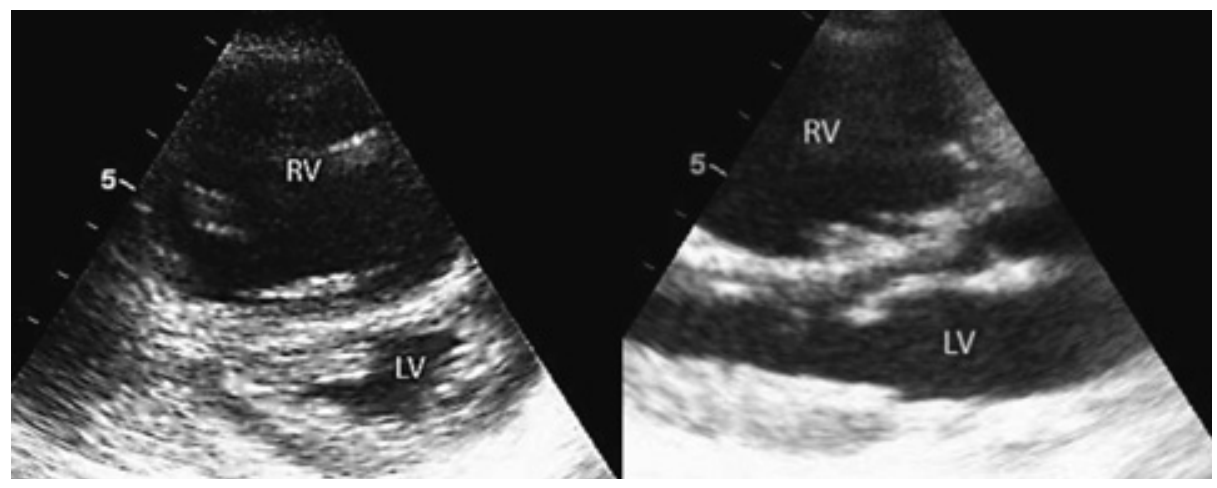

Figur 1 Ekkokardiografisk parasternalt kortaksebilde (venstre) og parasternalt langaksebilde (høyre) ved innkomst. Høyre ventrikkel (RV) er betydelig forstørret, septum buker mot venstre ventrikkel (LV) som på sin side er liten og har redusert fylling. Grunnet gjenopplivning og støyete EKG kan stillbildet derfor ikke tidsangis nærmere til hjertesyklus 


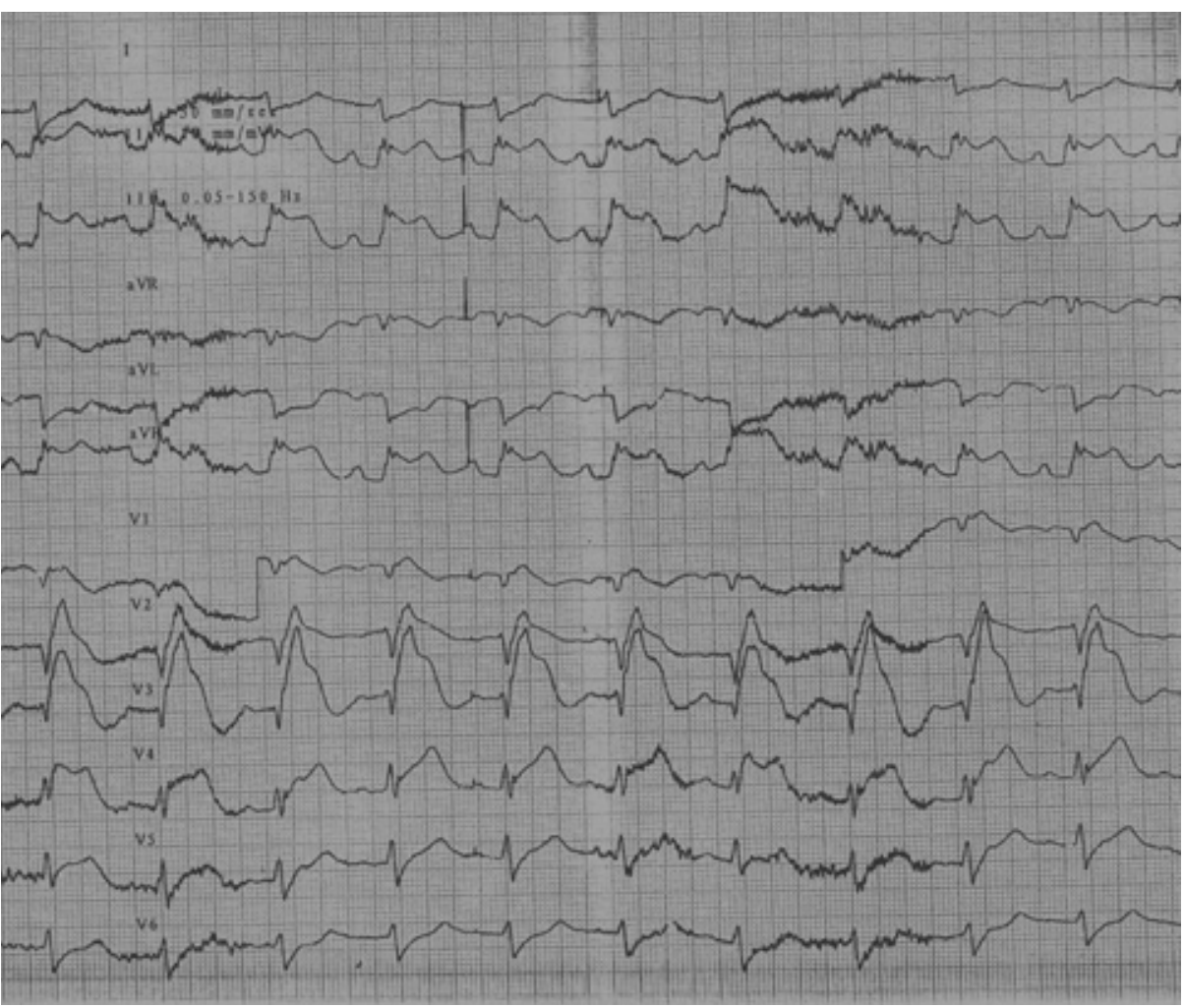

Figur 2 EKG ved innkomst med ST-elevasjon i flere avledninger

av blodstrømobstruksjon gjennom lungearteriene. Dette kan gi redusert fylling (preload) til venstre ventrikkel, og ekkokardiografisk vil det kunnes påvises en hyperdynamisk og tom venstre ventrikkel (fig 1). Hjerteminuttvolumet vil reduseres og kunne føre til blodtrykksfall og sirkulasjonskollaps.

Vi fant indikasjon for å gi fibrinolytisk behandling. 38 minutter etter innkomst ble det via perifer vene gitt heparin 2500 IE og bolus med 50 mg alteplase (Actilyse). Ti minutter etter oppstart kom det puls-givende sinusrytme 100-130 slag/min. Systolisk blodtrykk steg til 100-120 mm Hg, hun ble sedert og pustet spontant på tube.

Trombolytisk behandling gis sjelden i akuttmottaket ved vårt sykehus, da de fleste pasienter med hjerteinfarkt og ST-elevasjon overføres direkte til perkutan koronar intervensjon. Det ga derfor en viss forsinkelse at medikamentet måtte klargjøres og hentes fra en annen avdeling. Alteplase (Actilyse) virker ved å løse opp tromber ved at det aktiverer plasminogen til plasmin. Det har høy affinitet til fibrin. Ved anbefalte doseringer har det begrenset effekt på koagulasjonssystemet for øvrig. Nødvendige operative inngrep er derfor ikke kontraindisert etter gitt trombolytisk behandling (1). Det ble gitt lavere mengde heparin enn det som er angitt i retningslinjer (initialt $150 \mathrm{IE} / \mathrm{kg}$ ) (2), betinget $i$ en noe hektisk situasjon i mottakelsen.

Radiolog mente at lokal fibrinolytisk behandling direkte $i$ a. pulmonalis ikke ville gi tilstrekkelig rask effekt. Thoraxkirurg fant indikasjon for kirurgisk fjerning av trombemasser dersom situasjonen fortsatt var ustabil. Det var frem til dette tidspunktet gitt kolloid væske i form av hydroksyetylstivelse (Voluven) $1000 \mathrm{ml}$ og Ringer-acetat $3500 \mathrm{ml}$. Blodgassanalyse som ble tatt ti minutter etter gjenopprettet sirkulasjon, viste uendret
Tabell 1 Oversikt over blodgassverdier. T0 er tidspunkt ved innkomst

\begin{tabular}{|c|c|c|c|c|c|c|}
\hline & & $\mathrm{pH}$ & $\begin{array}{l}\mathrm{pCO}_{2} \\
(\mathrm{kPa})\end{array}$ & $\begin{array}{c}\mathrm{pO}_{2} \\
(\mathrm{kPa})\end{array}$ & $\begin{array}{c}\mathrm{BE} \\
\mathrm{mmol} / \mathrm{l}\end{array}$ & $\begin{array}{l}\text { Laktat } \\
\mathrm{mmol} / \mathrm{l}\end{array}$ \\
\hline 1 & $\mathrm{~T} 0+10 \mathrm{~min}$ & 6,83 & 7,7 & 40,8 & -22 & 14,0 \\
\hline 2 & $\mathrm{TO}+24 \mathrm{~min}$ & 7,09 & 7,1 & 46,2 & -12 & 14,0 \\
\hline 3 & $\mathrm{~T} 0+32 \mathrm{~min}$ & 7,04 & 9,5 & 51,4 & -11 & 13,4 \\
\hline 4 & T0+46 min Før transport St Elisabeth & 6,99 & 9,4 & 28,4 & -13 & 10,8 \\
\hline 5 & T0+90 min Operasjon start & 6,98 & 11,0 & 12,2 & -11 & 9,6 \\
\hline 6 & T0+200min Operasjon slutt & 7,32 & 4,8 & 15,4 & $-6,5$ & 6,2 \\
\hline
\end{tabular}

acidose (blodgass 5, tab 1). I Trondheim er thoraxkirurgisk enhet (St. Elisabeth) lokalisert $2 \mathrm{~km}$ fra mottakelsen. Pasienten ble overflyttet dit og tilstanden var relativt stabil før og under transporten. Etter overflytting til operasjonsbordet falt systolisk blodtrykk til cirka 40-50 $\mathrm{mm} \mathrm{Hg}$.

\section{Kirurgisk behandling}

Ny transtorakal ekkokardiografisk undersøkelse på operasjonsbordet viste uendrede funn. Sentralt venetrykk var $33 \mathrm{~mm} \mathrm{Hg}$ Inormalt $<10 \mathrm{~mm} \mathrm{Hg}$ ). Pasienten var på dette tidspunkt kritisk dårlig, og det ble utført akutt sternotomi (noe lettblødende i feltet). Etter standard heparinisering ble det startet ekstrakorporal sirkulasjon og nedkjøling til $32{ }^{\circ} \mathrm{C}$. Man valgte å foreta operasjonen med standard hjertekirugisk prosedyre med avklemming av aorta og kald krystalloid kardioplegi. A. pulmonalis ble åpnet med et langsgående snitt opp langs truncus pulmonalis og ut mot venstre lungearterie. Det var betydelige mengder koagler sentralt i lungearteriene. Med kateter ble det sugd ut flere grove og delvis organiserte tromber fra begge lungearterier, noen var sannsynligvis flere dager gamle (fig 3). Ved åpning av aortatang fikk pasienten spontan sinusrytme.

Med hemoglobinmål på $10 \mathrm{~g} / 100 \mathrm{ml}$ ble det gitt 7 enheter SAGMAN-blod. Grunnet mye blodsiving i operasjonsfeltet også etter reversering av heparin med standard dose protamin, ble det gitt 2 enheter trombocyttkonsentrat og 7 enheter ferskfryst plasma. Traneksamsyre (Cyclocapron) $3 g$ ble deponert $i$ operasjonsfeltet. Da pasienten ble koblet fra hjerte-lunge-maskin, fant man tegn til dilatert høyre ventrikkel med dårlig bevegelse. Man startet derfor levosimendan (Simdax)- infusjon $(0,2 \mu \mathrm{g} / \mathrm{kg} / \mathrm{min})$ uten bolus og samtidig noradrenalin for å opprettholde adekvat perfusjonstrykk. Dette førte raskt til betydelig bedre kontraksjoner, høyre ventrikkels dimensjon ble redusert og det kunne foretas ukomplisert frakobling av hjerte-lunge-maskin. Ved avsluttet kirurgisk intervensjon var sentralt venetrykk 13 $\mathrm{mm} \mathrm{Hg}$ og blodgassanalyse viste en halvering av laktatverdien (blodgass 7, tab 1). Gjennom hele forløpet var det maksimalt dilaterte pupiller.

Embolisme stimulerer fibrinolyse som kan gi blødningskomplikasjoner. Fibrinolysen hemmes av traneksamsyre. Ved større blødning og ved forbruk av koagulasjonsfaktorer, ved for eksempel trombedanning kan det bli underskudd på koagulasjonsfaktorer. Disse kan substitueres med ferskfryst plasma. Hos vår pasient var $\mathrm{Hb} 8,4 \mathrm{~g} / 100 \mathrm{ml}$ preoperativt, men blødning peroperativt og rikelig elektrolyttholdig væske gjorde at man ga blod for å holde hemoglobinnivået på ca $10 \mathrm{~g} / 100 \mathrm{ml}$.

Vår pasient hadde en sviktende høyre ventrikkel som følge av a.pulmonalis- 
obstruksjon. Levosimendan (Simdax) er en såkalt kalsiumsensitiserer. Det gir positiv inotrop effekt ved å bedre binding mellom intracellulært kalsium og troponin $\mathrm{C}$ som gir en mer effektiv kobling av aktin-myosinfilamenter. Det gir også åpning av ATPavhengige kaliumkanaler og har en viss hemming av fosfodiesterase. Dette hindrer nedbrytning av cAMP, og begge mekanismer gir vasodilaterende effekt. Vi har klinisk erfaring gjennom flere år med bruk av medikamentet $\mathrm{i}$ behandling av svikt av høyre og venstre ventrikkel både $\mathrm{i}$ forbindelse med hjertekirurgiske inngrep og medisinske tilstander. De mest fremtredende effekter er bedring i slagvolum og redusert fyllingstrykk. I de første studiene som kom, ble det anbefalt en støtdose. Dette sluttet vi med for å unngå det kraftige blodtrykksfallet man kan få på grunn av vasodilatasjon. Det er få systematiske studier på bruk ved høyre ventrikkel-svikt. Noen mindre studier viser forbedret systolisk forkortning, bedrede vevsdopplerfunn, reduksjon av nevrohormonal og inflammatorisk status med reduksjon av B-type natriumpeptid og reduksjon av det systoliske pulmonale arterielle trykket (3). Fremdeles må man bruke vasoaktive medikamenter som for eksempel noradrenalin for å motvirke blodtrykksfallet.

\section{Videre behandling}

Pasienten var resuscitert i cirka 45 min og vi var usikre på den cerebrale perfusjonen. Dilaterte pupiller kan ha flere årsaker, men vi valgte å unnlate full oppvarming og fortsatte aktiv kjøling med et eksternt vannbasert kjølesystem (CritiCool, MTRE, USA) med kroppstemperatur på $34{ }^{\circ} \mathrm{C}$ i 24 timer. Pasienten ble deretter overflyttet til Kardiologisk avdeling, Hjerteovervåking, det tredje postoperative døgn. Sedasjon ble stanset og hun våknet til og var mentalt adekvat i løpet av ett døgn. Hun ble mobilisert og overflyttet til lokalsykehuset ti dager etter innleggelsen. Ved utskrivning var hun cerebralt adekvat og uten nevrologiske utfall. Seks uker postoperativt ble det foretatt spiral-CT av lungearteriene og ultralydundersøkelse av underekstremitetene, med normale funn. Spirometri viste kun lett restriktivt mønster som kunne settes i sammenheng med gjennomgått sternotomi.

\section{Diskusjon}

Ekkokardiografi viste tegn på en hemodynamisk signifikant lungeemboli. Det er vanlig å se de funn vi gjorde: dilatasjon av høyre ventrikkel, redusert høyresidig kontraktilitet, økt diameter av høyre ventrikkel i forhold til venstre ventrikkel og deviasjon av septum mot venstre side. Man kan også se dilaterte proksimale pulmonalarterier, endret blodstrøm i utløpstractus på høyre side, trikuspidalinsuffisiens med jethastigheter omkring $3-3,5 \mathrm{~m} / \mathrm{s}$ og utvidet $\mathrm{v}$. cava med redusert inspiratorisk kollaps. Pasienter med normal ekkokardiografisk undersøkelse vil ha mindre sannsynlighet for signifikant lungeemboli (4). Et isolert høyre ventrikkel-infarkt vil kunne gi liknende ekkokardiografiske funn, men vanligvis ikke en slik betydelig dilatasjon av høyre ventrikkel med tegn på økte systoliske trykk.

Ved overflytting til lokalsykehuset viste ekkokardiografi normale dimensjoner på alle kamre, god kontraktilitet av venstre ventrikkel (fig 4), noe paradoks bevegelse av septum, ingen trikuspidalinsuffisiens, lett redusert funksjon av høyre ventrikkel bedømt ut fra vevsdopplerundersøkelse av trikuspidalannulus (grenseverdier).

$E K G$. Lungeemboli kan ofte gi dynamiske EKG-forandringer, slike funn er uspesifikke og normalt EKG utelukker ikke lungeemboli (5). Det mest spesifikke funnet er $\mathrm{S}_{\mathrm{I}} \mathrm{Q}_{\mathrm{III}} \mathrm{T}_{\text {III }}$ -mønster i standardavledningene med markert $\mathrm{S}$ i avledning I, Q i avledning III og negativ $\mathrm{T} i$ avledning III. Andre hyppige forandringer er høyredreining av aksen, komplett eller inkomplett høyre grenblokk og ST-forandringer i prekordialavledningene. Sinustakykardi er vanlig og supraventrikulære arytmier kan forekomme (6). ST-elevasjoner i ekstremitetsavledninger (I,II,III) og høyresidige prekordialavledninger (V1-V3) forekommer sjelden og kan være diagnostisk villedende. Vår pasient hadde høye STelevasjoner i avledninger tilsvarende nedrevegg (II,III,aVF) som medførte differensialdiagnostiske vurderinger opp mot hjerteinfarkt. Samtidige ST- elevasjoner i V2-V4 gjorde diagnosen mindre sannsynlig. Ved mistenkt lungeemboli må EKG-forandringer ikke vektlegges alene, men ses i sammenheng med øvrige funn.

Retningslinjer fra 2008 klassifiserer lungeemboli ut fra tidlig mortalitetsrisiko i hhv. høy risiko og ikke høy risiko. Sistnevnte klassifiseres videre $\mathrm{i}$ intermediær eller lav risiko (4). Høy risiko er karakterisert av sjokk og/eller hypotensjon, sistnevnte defineres som et systolisk blodtrykk $<90 \mathrm{~mm} \mathrm{Hg}$ eller blodtrykksfall $>40 \mathrm{~mm} \mathrm{Hg}$ med over $15 \mathrm{mi}-$ nutters varighet. Hos dem med intermediær risiko finner man hypokinesi av høyre ventrikkel og/eller myokardskade, men ellers sirkulatorisk stabilitet (4). Hemodynamisk stabile pasienter uten tegn til dysfunksjon av høyre ventrikkel defineres til lavrisikogruppen. Høyrisikopasienter har økt totalmortalitet som man kan forvente øker ytterligere dersom det inntrer sirkulasjonskollaps (7, 8). Systemisk fibrinolytisk behandling er assosiert med hemodynamisk forbedring (4). Det foreligger få studier med kliniske endepunkter, men enkelte mindre studier viser bedre overlevelse av systemisk fibrinolyse gitt sammen med heparin enn heparin alene (9). Fibrinolytisk behandling ved intermediærrisiko lungeemboli er kontroversielt. Ved lavrisiko lungeemboli synes konvensjonell antikoagulasjonsbehandling å være tilstrekkelig (4). Lokal fibrinolyse

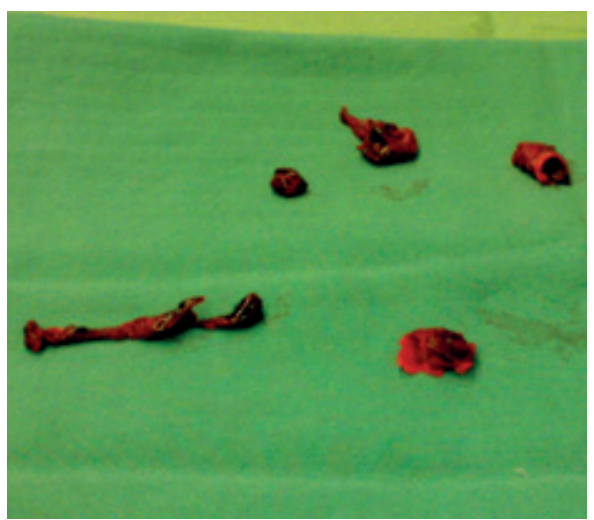

Figur 3 Trombotisk materiale som ble fjernet under operasjonen

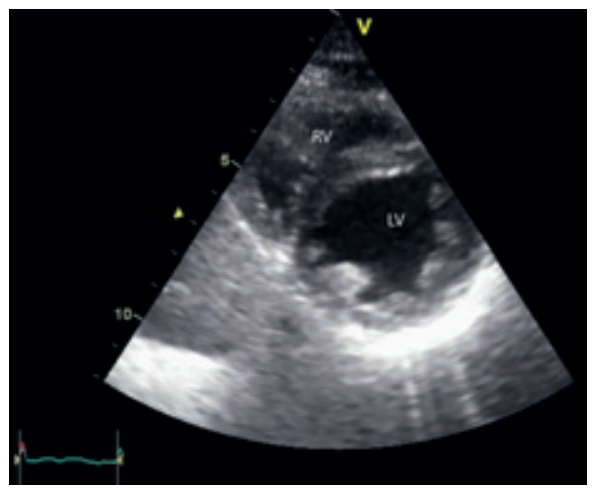

Figur 4 Ekkokardiografisk endediastolisk kor taksebilde ti dager etter innkomst. Venstre ventrikkel (LV) har nå en diameter større enn høyre ventrikkel (RV). Intraventrikulært septum buker ikke lenger inn mot LV

proksimalt for embolien gjennom pulmonalkateterisering er ikke vist å gi sikkert bedre oppløsning av tromber enn systemisk infusjon (10). Kateterstyrt embolektomi og direkte fragmentering er et alternativ som kan vurderes ved absolutt kontraindikasjon for fibrinolyse eller kirurgi.

Kirurgisk intervensjon kan være aktuelt hos pasienter med høyrisiko lungeemboli der det er kontraindikasjon mot fibrinolyse eller responsen på fibrinolyse er utilfredsstillende (4). De pasientene som synes best egnet for kirurgisk behandling, har subtotal obstruksjon av proksimale lungekar uten at det foreligger kronisk forhøyet lungearterietrykk. Ved operativt inngrep er det vist bedre overlevelse sammenliknet med repetert fibrinolytisk behandling hos dem som ikke responderer på den første dosen (11).

Pasientens mor har antitrombinmangel, hos vår pasient er det eneste patologiske funnet lett redusert antitrombinnivå som ble tolket som betinget i forbruk. Seks måneder før hendelsen skiftet hun sin monofasiske p-pille fra en med $20 \mu \mathrm{g}$ etinyløstradiol lbrukt i to år) til en med $30 \mu \mathrm{g}$ etinyløstradiol (Yasmin). Hun ble postoperativt anbefalt å bruke annen prevensjon enn p-piller, og erfaringsmessig er det gitt råd om liberal profylakse ved aktivitet som gir økt risiko for venetrom- 
bose. Hun ble gitt warfarin som planlegges brukt i minst to år før ny hematologisk vurdering.

Seks dager før innleggelsen merket pasienten en påfallende dyspné. Symptomene forverret seg dagen før innleggelse, og hun hadde planlagt å gå til lege.

$\mathrm{Vi}$ antar at bruk av p-piller bidro vesentlig til den aktuelle tromboemboliske hendelsen. Orale prevensjonsmidler øker risiko for tromboembolisk sykdom som øker ytterligere ved samtidig koagulasjonsforstyrrelse.

Pasienten har gitt samtykke til at artikkelen blir publisert.

Oppgitte interessekonflikter: Ingen
Litteratur

. Aklog L, Williams CS, Byrne JG et al. Acute pulmonary embolectomy: a contemporary approach. Circulation 2002; 105: 1416-9.

2. Jansen BF, red. Felleskatalogen. Oslo: Fagbokforlaget, 2009: 708 .

3. Parissis JT, Paraskevaidis I, Bistola V et al. Effects of Levosimendan on right ventricular function in patients with advanced heart failure. Am J Cardiol 2006: 98: 1489-92.

4. Task force for the diagnosis and managemen of acute pulmonary embolism of the European Society of Cardiology. Guidelines on diagnosis and management of acute pulmonary embolism. Eur Heart J 2008: 29: 2276-315

5. Lohan DG, Cronin CG, Meehan CP et al. Massive pulmonary embolus with hemodynamic compromise: therapeutic options. Emerg Radiol 2007: 13: $161-9$

6. Chou T. Electrocardiography in clinical practice. 2. utg. Orlando, FL: Grune \& Stratton, 1986 $309-17$.

7. Stulz P, Schläpfer R, Feer R et al. Decision making in the surgical treatment of massive pulmonary embolism Eur J Cardiothorac Surg 1994: 8 : 188-93.

8. Dauphine C, Omari B. Pulmonary embolectomy for acute massive pulmonary embolism. Ann Thorac Surg 2005; 79: $1240-4$

9. Konstantinides S, Geibel A, Heusel G et al. Heparin plus alteplase compared with heparin alone in patients with submassive pulmonary embolism. N Engl J Med 2002; 347: 1143-50.

10. Verstaete M, Miller GA, Bounameaux $\mathrm{H}$ et al. Intravenous and intrapulmonary recombinant tissue type plasminogen activator in the treatment of acute massive pulmonary embolism. Circulation 1988: 77: 353-60.

11. Meneveau N, Seronde MF, Blonde MC et al. Management of unsuccessful thrombolysis in acute massive pulmonary embolism. Chest. 2006; 129: $1043-50$

Manuskriptet ble mottatt 25.11. 2008 og godkjent 27.8. 2009. Medisinsk redaktør Odd Terje Brustugun.

\section{Kommentar}

\section{Nærhet til en hjerte-lunge-maskin}

Kardiogent sjokk betinget i massiv lungeemboli medfører høy mortalitet. Tilstanden kan reverseres ved rask diagnostikk og behandling. Dette demonstreres klart av Petter Vanke og medarbeidere, som ved hjelp av åpen pulmonal embolektomi lyktes $\mathrm{i}$ å bringe en 20-årig kvinne fra hjertestans til full restitusjon. En avgjørende suksessfaktor var nærhet til en hjerte-lunge-maskin. Idet pasienten kollapset sirkulatorisk for tredje gang, overtok en mekanisk pumpe og en oksygenator for det sviktende hjertet. Hun ble derved sikret oksygenering og sirkulasjon inntil obstruksjonen av de sentrale lungekarene var hevet kirurgisk og hjerte- og lungefunksjonen gjenopprettet.

De kardiopulmonale kompensasjonsmekanismene er utilstrekkelige ved en akutt tromboembolisk obstruksjon av mer enn $50 \%$ av lungekarsengen. Den umiddelbare økningen av arterietrykket (afterload) medfører høyere veggtensjon i høyre ventrikkel, som dilaterer og svikter. Høyre ventrikkels reduserte ytelse begrenser fyllingen av venstre ventrikkel slik at minuttvolumet faller også i systemkretsløpet. Respirasjonssvikt kan inntre sekundært til de hemodynamiske forstyrrelsene. Et fatalt forløp skyldes i de fleste tilfeller akutt eller progredierende høyre ventrikkel-svikt $(1,2)$.

De fleste dødsfall ved lungeemboli inntrer kort etter symptomdebut (2). Man må derfor raskt ta stilling til om man vil gi trombolytisk behandling i tillegg til antikoagulasjon. Hos pasienter med høy risiko for umiddelbar død anbefales trombolytisk behandling, administrert enten systemisk eller via kateter direkte i lungekretsløpet (1-3). I risikovurderingen vektlegges særlig graden av sirkulasjonssvikt, høyre ventrikkel-dys- funksjon og utslipp av myokardmarkører. Trombolytisk behandling akselererer oppløsning av trombene, fremmer normalisering av høyre ventrikkels pumpefunksjon og bedrer etter alt å dømme overlevelsen hos høyrisikopasienter. Trombolytisk behandling øker imidlertid risikoen for fatale blødninger og invalidiserende apopleksi $(1,3)$.

Forutsatt tilgang på hjertekirurgisk service må embolektomi vurderes når farmakologisk trombolyse har mislyktes eller er forbundet med uakseptabel blødningsfare. Inngrepet er aktuelt også for pasienter under pågående resuscitering, når trombolytika ikke kan forventes å virke tilstrekkelig raskt, og når det finnes tilleggsindikasjon for umiddelbar hjertekirurgi (f.eks. lukning av foramen ovale) $(1,3)$. Inngrepet utføres med støtte av hjerte-lunge-maskin, i normotermi og som regel uten at hjertet stanses. Truncus pulmonalis åpnes og tromboembolisk materiale evakueres $(1,3)$.

Hjerte-lunge-maskinen er ikke forbeholdt operasjonsstuen, men kan også fylle en fremskutt rolle i behandlingskjeden. Pasienter i kardiogent sjokk forårsaket av lungeemboli, hjerteinfarkt eller myokarditt kan i akuttmottaket, i løpet av få minutter etter innleggelse og under pågående resuscitering tilkobles en transportabel ekstrakorporal membranoksygenerings- (ECMO)-enhet via perkutane kanyler i femoralkarene. Man oppnår derved effektiv oksygenering og organperfusjon samt umiddelbar avlastning av hjertet mens pasienten gjennomgår diagnostikk og etter hvert definitiv behandling. I en nylig publisert multisenterstudie kunne 79 av 295 pasienter ( $27 \%$ ) skrives ut i live etter ECMO-støttet resuscitering (4). Mer utstrakt bruk av dette behandlingsprinsippet i Norge imøteses.
Oppgitte interessekonflikter: Ingen

\section{Kristian Bartnes}

kristian.bartnes@unn.no

Hjerte-, lunge- og karkirurgisk avdeling

Universitetssykehuset Nord-Norge

9038 Tromsø

\section{Litteratur}

1. Torbicki A, Perrier A, Konstantinides $\mathrm{S}$ et al. Guidelines on the diagnosis and management of acute pulmonary embolism. Eur Heart J 2008; 29 : $2276-315$

2. Tapson VF. Acute pulmonary embolism. N Engl J Med 2008; 358: 1037-52.

3. Kearon C, Kahn SR, Agnelli G et al. Antithrombotic therapy for venous thromboembolic disease. American College of Chest Physicians evidence based clinical practice guidelines (8th Edition). Chest 2008; 133 (suppl): 454-545.

4. Thiagarajan RR, Brogan TV, Scheurer MA et al. Extracorporeal membrane oxygenation to support cardiopulmonary resuscitation in adults. Ann Thorac Surg 2009; 87: 778-85

Manuskriptet ble mottatt 30.9. 2009 og godkjent 15.10. 2009. Medisinsk redaktør Odd Terje Brustugun. 